\title{
The Study on Relationship between Job Satisfaction and Life Satisfaction of Bangladeshi Migrant Workers in South Korea
}

\author{
S. M. Mustafizur Rahman $\cdot$ Beo-Deul $\mathrm{KANG}^{\dagger} \cdot$ Jong-Un PARK
}

(Pukyong National University)

\section{한국의 방글라데시 이주 노동자의 직업만족도와 삶만족도 사이의 관계에 대한 연구}

\author{
모스타피져 라만 - 강버들 ${ }^{\dagger}$. 박종운 \\ (부경대학교)
}

\begin{abstract}
2012년 통계청 자료에 의하면 한국에 체류하는 외국인은 약 160 만명이고, 그 중 방글라데시 노동자 는 약 4.7\%(한국고용정보원, EPS, 2012)라고 한다. 본 논문의 연구를 위하여 김해(100명), 마산(60명), 인천(40명)에 거주하고 있는 방글라데시 이주 노동자 약 200 명에 대하여 설문조사를 실시하였다. 이 연구의 목적은 그들의 직업만족도와 삶의 만족도 사이에는 어떤 관련성이 있는지, 그들의 한국에서의 삶의 만족도를 높이기 위한 방안은 무엇인지에 대하여 알아보고자 하는 것이다. 연구 결과 직업 만족 도의 $\alpha$ 값은 0.71 , 삶의 만족도에 대한 $\alpha$ 값은 0.72 이었다. 직업만족도에 대한 설문은 Paul E. Spector(1985)가 고안한 것을 사용하였으며, 삶의 만족도에 대한 설문은 Thomas M. Krapu외 4인이 연 구한 것을 사용하였다. 연구 결과 방글라데시 이주 노동자의 직업만족도와 삶의 만족도 사이에는 강 한 관련성이 있으며, 그들이 느끼는 삶의 만족도는 매우 낮았다. 이를 높이기 위해서는 정부와 시민 단체들의 적극적인 지원이 필요하다고 분석되었다.
\end{abstract}

Key words : Job satisfaction, Life satisfaction, Bangladeshi migrant workers

\section{I . Introduction}

With the economic and technological development in the society, people place more importance on the quality of life than before. Nowadays, people emphasize not only work environment, but also non-work-related life. Therefore, understanding employees' life satisfaction is becoming more important. A Pan EU study (European Commission, 2006) found that when people are satisfied with their jobs, they are satisfied with their non-work-related life and become happier. Developed countries are paying much attention to understand citizens' life satisfaction (Lian, 2008).

Why does one become a migrant worker? A simplest answer based on conventional wisdom will be that economic concerns or aspirations for a good life are primary reasons for decision to migrate. Literatures on economic aspects of migration, focusing mostly on remittance and investment of money earned overseas, are rich

† Corresponding author : 051-629-7844, badlle@hanmail.net 
(IOM, 2002). Migration, globalization and human rights have emerged as central social, economic and political challenges reshaping the world at the turn of the century. The most immediate challenge facing with societies worldwide is the appalling rise in violence against migrants and the restrictive government measures that undermine the fundamental basic human rights of millions of migrants and their families.

According to UN estimates, over 190 million people are now living permanently or temporarily outside their countries of origin. One out of every 35 people worldwide is currently an international migrant. This vast number includes migrant workers and their families, refugees, asylum seekers and immigrants. However, this does not take into account those of irregular or undocumented status, for there are no reliable estimates.

These migrants often become universal "scapegoats," targeted for violence and excluded from legal protections in many places due to their immigration status or nationality. The increased designation of migrants as 'illegal' further aggravates the deprivation of rights entitled to everyone under international human rights law. Historically, little international attention, advocacy, and public education had been devoted to upholding the human rights and dignity of migrants other than refugees, despite the elaboration of international human rights standards for migrants and declarations in international conferences calling for cooperation towards the protection of migrants' rights. Thus, in 1994, international representatives of church, human rights, migrant and trade unions, inter-governmental agencies, and national and grassroots civil society organizations came together to establish the "International Migrants Rights Watch Committee," which was renamed Migrants
Rights International (MRI) in 2000.

This research aims at contributing to understanding studies on Bangladeshi migrant workers and looks into demographic profiles, and their job satisfaction and life satisfaction. This study specially seeks:

First, to understand the demographic profile of the Bangladeshi migrant workers in South Korea.

Second, to identify the correlation between job satisfaction and life satisfaction with the influence of demographic profiles.

Third, to provide a good scenario about the present situation of the Bangladeshi migrant workers in South Korea.

Finally, to highlight the key issues and help develop an understanding of service provision issues for Bangladeshi migrant workers in South Korea.

\section{II . Literature review}

One common research finding is that job satisfaction is correlated with life satisfaction (Rain, 1991). This correlation is reciprocal, which means that people who are satisfied with life tend to be satisfied with their job and people who are satisfied with their job tend to be satisfied with life. However, some research has found that job satisfaction is not significantly related to life satisfaction when other variables such as non-work satisfaction and core self-evaluations are taken into account (Rode, 2004).

Researches have established the relationship between job and life satisfaction as being significant and positive (Pearson correlation coefficient ranging from 0.31 to 0.44 ) (De Cuyper \& De Witte, 2006; Moser \& Schuler, 2004; Rode, 2004)). Three perspectives are often suggested to 
explain the significant job-life satisfaction correlation (Rode, 2004). The first assumes that job and life satisfaction are the same construct, with job satisfaction serving as an underlying dimension of overall life satisfaction. The second approach assumes a more top-down approach in which life satisfaction influences job satisfaction, such that those who have a disposition to be satisfied in life also tend to find satisfaction on the job. A final approach assumes a more bottom-down approach in which common influences generate the relationship between the two variables. Thus this approach assumes that the significant relationship between life and job satisfaction is the result of spurious correlation.

Despite the number of approaches that have been introduced to explain why the relationship exists, research clearly distinguishing causality has continued to elude researchers (Rode, 2004). In a study designed to specifically distinguish the cross $^{-}$ sectional and longitudinal nature of the job-life satisfaction relationship, Judge and Watanabe (1993) supported the two constructs as reciprocal, with life satisfaction exerting a significantly stronger effect on job satisfaction. However, it has been suggested that future studies focus on exploring the role of additional individual and work factors (e.g., cognitive processes, workload, coreself -evaluations etc.) and explaining the causal nature of the job-life satisfaction relationship (Judge \& Watanabe, 1993; Moser and Schuler, 2004, Rode, 2004).

\section{Methodology}

A quantitative research was carried out to investigate the participant's demographic characteristics, their job satisfaction and life satisfaction. A total of
200 Bangladeshi migrant workers in Korea (100 respondents from Gimhae, 40 from Incheon commercial area and 60 from Masan industrial area) were participated in this study through survey method.

\section{Materials}

Descriptive statistics (mean, standard deviation, minimum, maximum, skew, \& kurtosis), reliability analysis, correlation and hierarchical regressions were applied to analyze the data using SPSS version 16. Most constructs/measures were of multiple items, which required the respondent to rate items on a scale. Reliability coefficients for all measures was checked and was very satisfactory (Cronbach alpha .70 and above). The social demographic variables such as age, hometown, marital status, religion, education, job category and duration of work were ascertained directly from the questionnaire.

In this research, job satisfaction was measured with the Job Satisfaction Survey (JSS) designed by Paul E. Spector(1985), University of South Florida . A total of 13 questionnaires were constructed for job satisfaction survey. This kind of measurement is to measure job satisfaction from human service employee. Overall, JSS presents evidence for the scale's reliability and constructs validity of specific applicability to human services. JSS uses a fivepoint Likert scale ranging from very dissatisfied (1) to very satisfied (5). The expected level of jobs satisfaction is 3.8 .

On the other hand, Life Satisfaction Survey (LSS) which is designed by Krapu T. M., Meinke L., Kramer, L., Friedman, R., and Voda, J.(2006) was administered to measure life satisfaction. In this research, a total of 7 questionnaires were 
constructed for life satisfaction survey. LSS contains a five point rating scale (never feel this way 1 , rarely feel this way 2 , sometimes feel this way 3 , often feel this wa4 y, always feel this way 5).

\section{Sampling procedure}

Survey was conducted by the direct contact with the participants. It can be divided into the following three types:

Single industry based survey: This type survey was done to collect the same industry personnel response. At first, for this survey the industry information was collected.

Group based survey: Group survey was done mostly on Sunday, the off day basis. Some particular area was discovered first to know the mostly group formed participants.

Personal contact survey: This survey was done by personally contacted basis.

\section{Analyses}

The data were examined using descriptive statistics (mean, standard deviation, minimum, maximum, skewness, and kurtosis). No significant missing data were found. Frequencies of the demographic variables were analyzed in the bar charts form. Then bivariate correlation analysis was done between the job satisfaction and life satisfaction to evaluate the correlation coefficients. Linear regressions were also used to determine the relation of job satisfaction with life satisfaction in controlling the demographic variables. Finally by controlling the age factor and education level separately, linear regression analysis is done to identify the effect of the age factor and the education level on the relationship of the job and life satisfaction.

\section{Results and Discussion}

\section{Descriptive statistics}

Descriptive analysis was done for the 13 job satisfaction questionnaires (Table 1) and for the 7 life satisfaction questionnaires (Table 2).

$\langle$ Table 1> Descriptive Statistics of Job Satisfaction

$(\mathrm{N}=200)$

\begin{tabular}{l|c|c|c|c|c|c}
\hline & \multirow{2}{*}{$\mathrm{M}$} & \multirow{2}{*}{$\mathrm{SD}$} & \multicolumn{2}{|c|}{ Skewness } & \multicolumn{2}{c}{ Kurtosis } \\
\cline { 4 - 6 } & & & Statistic & Std. Error & Statistic & Std. Error \\
\hline \hline Payment of a fair amount for the work I do & 4.14 & .680 & -.278 & .172 & -.464 & .342 \\
Chance for promotion on my job & 3.52 & .879 & .521 & .172 & -.531 & .342 \\
Unsatisfaction with the benefits & 3.06 & .909 & .580 & .172 & .681 & .342 \\
Recognition for job & 4.50 & .549 & -.460 & .172 & -.909 & .342 \\
Sociable personality & 4.66 & .497 & -.903 & .172 & -.601 & .342 \\
Benefits of organization & 3.96 & .762 & .068 & .172 & -1.271 & .342 \\
Optimistic on job & 4.70 & .576 & -.351 & .172 & 6.884 & .342 \\
Self-respect of job & 2.77 & 1.156 & .864 & .172 & -.321 & .342 \\
Salary satisfaction & 2.98 & 1.015 & .342 & .172 & -.020 \\
Favor with supervisor & 4.67 & .586 & -1.752 & .172 & 2.754 & .342 \\
Eenjoyment for job & 2.65 & 1.217 & .728 & .172 & -.360 \\
Accordance with employment contracts & 4.58 & .719 & -1.454 & .172 & .829 \\
Satisfaction for vacation & 4.61 & .538 & -.938 & .172 & -.203 \\
\hline
\end{tabular}




\begin{tabular}{l|c|c|c|c|c|c}
\hline & $\mathrm{M}$ & \multicolumn{2}{|c|}{ SD } & \multicolumn{2}{c}{ Skewness } & \multicolumn{2}{c}{ Kurtosis } \\
\cline { 2 - 7 } & Statistic & Statistic & Statistic & Std. Error & Statistic & Std. Error \\
\hline \hline Passion and joy on lif & 3.55 & 1.106 & -.463 & .172 & -.513 & .342 \\
Dreams, hopes and aspirations & 3.39 & 1.243 & -.364 & .172 & -.853 & .342 \\
Optimistic person & 2.64 & 1.108 & .325 & .172 & -.574 & .342 \\
Positive thinnking & 3.31 & 1.237 & -.309 & .172 & -.859 & .342 \\
Humor, laughter, and playfulness & 3.02 & 1.171 & .217 & .172 & -.952 & .342 \\
Balance between career and persona & 2.81 & 1.109 & .427 & .172 & -.342 & .342 \\
Emotiona lbalance & 2.84 & 1.029 & .298 & .172 & -.074 & .342 \\
\hline
\end{tabular}

\section{Demographic analysis}

To provide a better picture of the participants, demographical profile including age, hometown, marital status, education level, present job and religion were analyzed(Table 3 ).

$\langle$ Table 3> Demographic analysis

$(\mathrm{N}=200)$

\begin{tabular}{|c|c|c|c|}
\hline $\begin{array}{c}\text { Demographic } \\
\text { variables }\end{array}$ & Category & Frequency & Percent \\
\hline \multirow{3}{*}{ Age } & $20-30$ yrs & 83 & 41.5 \\
\hline & $30-40 \mathrm{yrs}$ & 116 & 58.0 \\
\hline & $>40 \mathrm{yrs}$ & 1 & .5 \\
\hline \multirow{6}{*}{ Hometown } & Dhaka & 47 & 23.5 \\
\hline & Rajshahi & 28 & 14.0 \\
\hline & Chittagong & 4 & 2.0 \\
\hline & Barishal & 39 & 19.5 \\
\hline & Khulna & 80 & 40.0 \\
\hline & Sylhet & 2 & 1.0 \\
\hline \multirow{2}{*}{$\begin{array}{l}\text { Marital } \\
\text { Status }\end{array}$} & Single & 76 & 38.0 \\
\hline & Married & 124 & 62.0 \\
\hline \multirow{3}{*}{$\begin{array}{l}\text { Education } \\
\text { Level }\end{array}$} & Elementary & 8 & 4.0 \\
\hline & High school & 140 & 70.0 \\
\hline & College & 52 & 26.0 \\
\hline \multirow{3}{*}{$\begin{array}{l}\text { Present Job } \\
\text { Status }\end{array}$} & Manufacturing/pro & 124 & 62.0 \\
\hline & duction & 59 & 29.5 \\
\hline & $\begin{array}{c}\text { Managerial post } \\
\text { Caretaker }\end{array}$ & 17 & 8.5 \\
\hline \multirow{2}{*}{ Religion } & Islam & 164 & 82.0 \\
\hline & Hindu & 36 & 18.0 \\
\hline
\end{tabular}

(1) Age

The age distribution showed that the most of the respondents were in the range of 30-40 years old $(58 \%)$. Age limit is analyzed because the most of the job are 3D (Difficult, Dirty, Dangerous). Most of the people are found adult and energetic to do the $3 \mathrm{D}$ jobs.

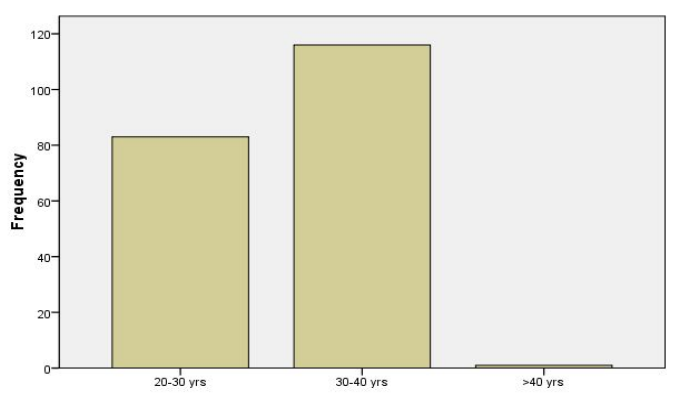

[Fig. 1] Age limit

(2) Hometown

The highest respondents were coming from the southern part of Bangladesh, Khulna division $(40 \%)$. Hometown is derived from this research because there are some particular region is marked for highest remittance earning zone. In this research the region is found at Khulna.

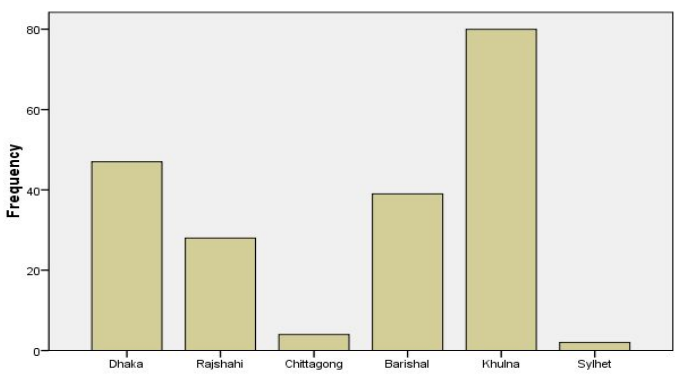

[Fig. 2] Hometown of the respondents 


\section{(3) Marital Status}

Married people (62\%) were larger than single type of people. In this research it was focused whether the earned money is utilized by the family or not, that is, whether the family is dependent on the employee's earnings or other context. Most of the married people have 3D jobs without changing job status because most of the family is dependent on the earnings of the employee.

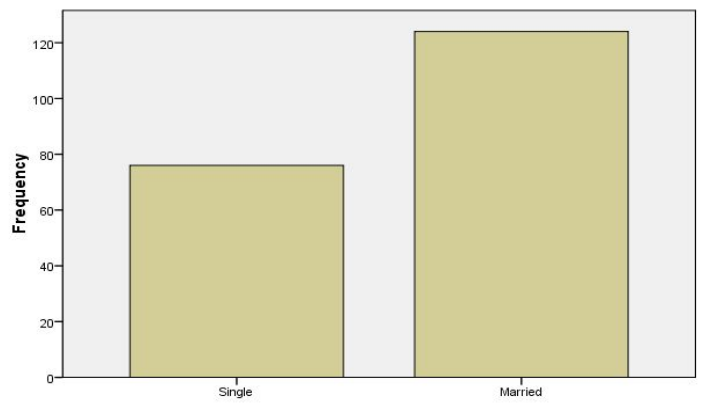

[Fig. 3] Marital Status of the respondent

\section{(4) Education Level}

Education level is analyzed because most of the workers are coming as a unskilled worker or semiskilled worker. So, education level is very much important to learn the skill as fast as possible. In this case the minimum education level is helping them to be a skilled labor very fast. And education level is also important to know the working conditions, wages, human rights etc..

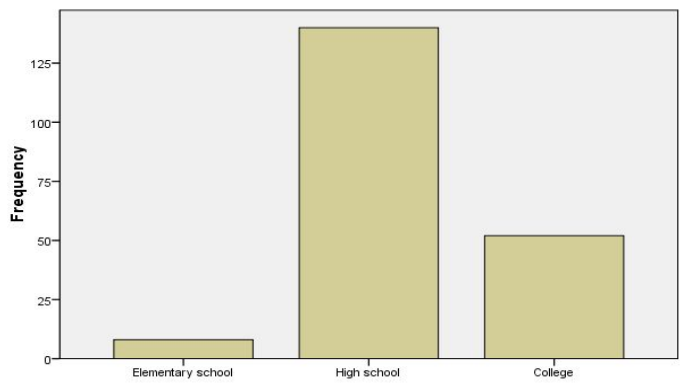

[Fig. 4] Education Level
Education levels of the largest number of respondents were high school $(70.0 \%)$, so most of the workers have basic education.

\section{(5) Present Job Status}

In term of present job status, the majority of the respondents $(62 \%)$ were as production employee or manufacturer. Present job status is related with the experiences and the preferences of the employee. It is also related with the salary, the job types and the secure place. In some cases the job is difficult but the salary is very high, so the employees prefer this type of job for a little while. Also some people are doing same job year after year only for the experience.

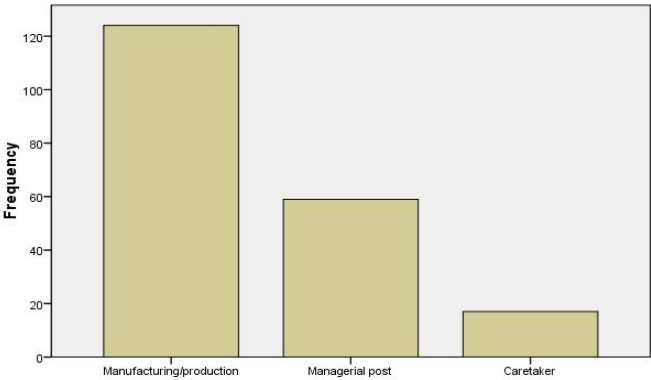

[Fig. 5] Present Job Statuses

\section{Reliability analysis}

Cronbach's $\alpha$ is employed to test instrument reliability. Hair et al. (1998) indicated that "Cronbach's alpha is used to measure reliability that ranges from 0 to 1 , with values of .60 to .70 deemed as the lower limit of acceptability." In this study, the $\alpha$ value of job satisfaction is 0.71 , and life satisfaction is 0.72 respectively. All the values are higher than 0.7 and therefore are reasonably acceptable.

\section{Correlation analysis}

Previous research has been given the correlational 
relationship between job satisfaction and life satisfaction is strong. (De Cuyper \& De Witte, 2006; Moser \& Schuler, 2004; Rode, 2004)). In this study the correlation between life satisfaction and job satisfaction was also significant at Pearson correlation coefficient $.20(\mathrm{p}<.05)$.

\section{Linear regression analysis}

Hierarchical regression analysis showed that life satisfaction was predicted by job satisfaction under controlling for demographic variables. The relationship was significant between job satisfaction and life satisfaction at $\mathrm{F}$ value $1.96(11, \mathrm{p}<.05)($ Table 4$)$.

$\langle$ Table 4$\rangle$ Linear regression model of job satisfaction(JS) and life satisfaction(LS)

Coefficients $^{\mathrm{a}}$

\begin{tabular}{|c|c|c|c|c|c|c|}
\hline & \multirow[t]{2}{*}{ Model } & \multicolumn{2}{|c|}{ Unstandardized Coefficients } & $\begin{array}{c}\text { Standardized } \\
\text { Coefficients }\end{array}$ & \multirow[t]{2}{*}{$\mathrm{t}$} & \multirow[t]{2}{*}{ Sig. } \\
\hline & & $\mathrm{B}$ & Std. Error & Beta & & \\
\hline \multirow[t]{12}{*}{1} & (Constant) & 13.366 & 6.034 & & 2.215 & .029 \\
\hline & Marital & -1.609 & 1.145 & -.162 & -1.406 & .163 \\
\hline & Manager & -2.472 & 1.502 & -.159 & -1.646 & .103 \\
\hline & Caretaker & -.137 & 1.702 & -.008 & -.080 & .936 \\
\hline & Dhaka & .759 & 1.082 & .072 & .702 & .484 \\
\hline & Rajshahi & .626 & 1.315 & .049 & .476 & .635 \\
\hline & Barishal & .351 & 1.426 & .025 & .246 & .806 \\
\hline & Chittagong & -8.712 & 3.014 & -.282 & -2.890 & $.005 * *$ \\
\hline & Sylhet & -2.023 & 4.719 & -.038 & -.429 & .669 \\
\hline & Highest degree obtained & -.556 & 1.061 & -.048 & -.524 & .602 \\
\hline & Age limit & -.121 & 1.083 & -.013 & -.112 & .911 \\
\hline & JS Total & .196 & .093 & .193 & 2.108 & $.037 *$ \\
\hline
\end{tabular}

a. Dependent Variable: LS Total

Constant value $13.366, \mathrm{R} 2$ value $.167 \quad * \mathrm{p}<.05, * * \mathrm{p}<.01$

(1) Controlling higher education

Education is basic criteria to understand the working condition, worker job satisfaction and the variation of the life satisfaction. But in this research there is no strong effect to the relation of job satisfaction and life satisfaction at $F$ value 2.16 $(10, \mathrm{p}<.05)($ Table 5$)$.

\section{$\langle$ Table 5> Linear regression model for higher education}

Coefficients $^{\mathrm{a}}$

\begin{tabular}{|c|c|c|c|c|c|c|}
\hline \multirow{2}{*}{\multicolumn{2}{|c|}{ Model }} & \multicolumn{2}{|c|}{ Unstandardized Coefficients } & \multirow{2}{*}{$\begin{array}{c}\text { Standardized Coefficients } \\
\text { Beta }\end{array}$} & \multirow{2}{*}{$\mathrm{t}$} & \multirow{2}{*}{ Sig. } \\
\hline & & $\mathrm{B}$ & Std. Error & & & \\
\hline \multirow[t]{11}{*}{1} & (Constant) & 12.339 & 5.688 & & 2.169 & ".032 \\
\hline & Marital & -1.611 & 1.141 & -.162 & -1.412 & .161 \\
\hline & Manager & -2.567 & 1.486 & -.166 & -1.728 & .087 \\
\hline & Caretaker & -.151 & 1.696 & -.009 & -.089 & .929 \\
\hline & Dhaka & .755 & 1.078 & .072 & .701 & .485 \\
\hline & Rajshahi & .573 & 1.307 & .045 & .438 & .662 \\
\hline & Barishal & .208 & 1.395 & .015 & .149 & .882 \\
\hline & Chittagong & -8.928 & 2.976 & -.289 & -3.000 & $.003 * *$ \\
\hline & Sylhet & -2.040 & 4.703 & -.038 & -.434 & .665 \\
\hline & Age limit & -.105 & 1.079 & -.011 & -.097 & .923 \\
\hline & JS Total & .194 & .093 & .191 & 2.095 & $.038^{*}$ \\
\hline
\end{tabular}

a. Dependent Variable: LS Total

Constant value 12.33 , R2 value $.165 * \mathrm{p}<.05,{ }^{*} \mathrm{p}<.01$ 
(2) Controlling age limit

Age also good criteria to assume the job satisfaction and life satisfaction relationship. But for the Bangladeshi migrants worker in Korea, there is no significant age effect at the relation of job satisfaction and life satisfaction at $\mathrm{F}$ value 2.40 (9, $\mathrm{p}<.05)($ Table 6).

$\langle$ Table 6$\rangle$ Linear regression model for age limit

Coefficients $^{\mathrm{a}}$

\begin{tabular}{|c|c|c|c|c|c|c|}
\hline & \multirow{2}{*}{ Model } & \multicolumn{2}{|c|}{ Unstandardized Coefficients } & Standardized Coefficients & \multirow{2}{*}{$\mathrm{t}$} & \multirow{2}{*}{ Sig. } \\
\hline & & B & Std. Error & Beta & & \\
\hline \multirow[t]{10}{*}{1} & (Constant) & 12.031 & 4.699 & & 2.561 & .012 \\
\hline & Marital & -1.552 & .958 & -.156 & -1.619 & .108 \\
\hline & Manager & -2.573 & 1.478 & -.166 & -1.741 & .084 \\
\hline & Caretaker & -.172 & 1.674 & -.010 & -.103 & .918 \\
\hline & Dhaka & .735 & 1.053 & .070 & .698 & .487 \\
\hline & Rajshahi & .553 & 1.284 & .044 & .430 & .668 \\
\hline & Barishal & .191 & 1.378 & .014 & .139 & .890 \\
\hline & Chittagong & -8.950 & 2.954 & -.290 & -3.030 & $.003 * *$ \\
\hline & Sylhet & -2.033 & 4.681 & -.038 & -.434 & .665 \\
\hline & JS Total & .195 & .092 & .192 & 2.117 & $.036^{*}$ \\
\hline
\end{tabular}

a. Dependent Variable: LS Total

Constant value $12.03, \mathrm{R} 2$ value $.165 * \mathrm{p}<.05, * * \mathrm{p}<.01$

\section{Discussion}

Measures of comparatively emerging job satisfaction along with demographic information allows of the prediction of satisfaction or dissatisfaction in individual's life. Primarily due to demographic factors, we can have limited success to predict individuals who are happy in life. under controlling the demographic variables, there is a significant relationship between job satisfaction and life satisfaction. And it is clear in this study that when the foreign Bangladeshi migrant workers are happy with their own job, there is an influence of job satisfaction on life satisfaction. Hometown is always a factor to the relationship between the job satisfaction and life satisfaction. Age is influence no major effect on the relationship between job and life satisfaction, and education level also have no strong effect on this relationship.

\section{CONCLUSION}

The result of the present study suggests that relationships between job and life satisfaction of Bangladeshi migrant workers has strong relationship. The investigation established a strong dependency of the life satisfaction of the Bangladeshi migrant workers in South Korea on job satisfaction. The workers who have difficulties in their own job have some difficulties in their daily life satisfaction. Finally, the findings also indicate that job satisfaction positively affects life satisfaction whether the demographic variables are settled down or not. Most of the Bangladeshi migrant workers in South Korea is not highly educated. Their view on life satisfaction perspective is very narrow. Many of the people are illegal also. So they have littlt concern with their life satisfaction phenomena. But this situation have been changing and in near future life satisfaction of the migrant Bangladeshi people in South Korea would be a nice research topic as the International Organization for Migration (IOM, UNDP) has been increasing concern with the migrant 
worker life satisfaction with the involvement of the targeted country. Large extent of sampling is necessary for future research because the sample size is very much limited in this study.

\section{Reference}

BMET(2011). Bureau of Manpower, Employment and Training, Ministry of expatriates, welfare and overseas employment, Govt, of the people's republic of Bangladesh.

http://www.bmet.org.bd/BMET/index.[Access: 10th January, 2011]

De Cuyper, N. \& De Witte, H.(2006). Autonomy and workload among temporary workers: Their effects on job satisfaction, organizational commitment, life satisfaction, and self rated performance, International Journal of Stress Management, 13, 441 459.

Diener, Ed, Emmons - Robert A. - Larsen, Randy J. \& Griffin, Sharon,(1985). The Satisfaction with Life Scale, Journal of Personality Assessment, 49(1), 71 75.

European Commission,(2006), "Job Satisfaction Key to Happiness, EU Study Reveals" http://ec.europa.eu/research/headlines/news /article_06_08_09_en.htm

Hair, J. F. - Tatham, R. L. - Anderson, R. E. \& Black, W.(1998). Multivariate Data Analysis (5th ed.), Prentice Hall.

IOM,(2002). International Organization for Migration, Recruitment and replacement of Bangladeshi migrant workers an evaluation of the process, United Nations Development Program, Dhaka.

Judge, T. A. \& Watanabe, S.(1993). Another look at the job satisfaction life satisfaction relationship, Journal of Applied Psychology, 78, 939 948.

KDS, "Korean Diasporas Statistics". Overseas Korean Foundation, Korea Immigration Bureau, June, 2008. http://www.immigration.go.kr/indeximmeng.html.

[Access: 10th January, 2011]

Krapu T. M. • Meinke L. - Kramer, L. • Friedman, R. - and Voda, J.(2006). The life satisfaction survey (LSS): Development of the instrument, Proceedings of the fourth International Coach Federation Coaching Research symposium, Lexington, KY:
Internationl Coach Federation.

KSO,(2006). Korean Statistics Office. http://kostat.go.kr/eng/.[Access:5th February, 2011]

Lian, J. W.(2008). Job stress, job satisfaction and life satisfaction between managerial and technical is personnel, Department of Information Management, National Central University, Taiwan.

Locke, E. A.(1976). The nature and causes of job satisfaction. In Dunnette, M.D. (ed.), Handbook of Industrial and Organizational Psychology, Chicago: Rand McNally.

MOFA,(2011). Ministry of Foreign Affairs, Govt. of the people's republic of Bangladesh.

Moser, K. \& Schuler, H.(2004). Is involvement a suppressor of the job satisfaction life satisfaction relationship? Journal of Applied Social Psychology, 34, 2377 2388.

Mount, M. · Ilies, R. \& Johnson, E.(2006). Relationship of personality traits and counterproductive work behaviors: The mediating effects of job satisfaction, Personnel Psychology, 59, 591 622.

MRI, (2000). Migrants Rights International, http://www.migrantwatch.org/.[Access: 23rd March, 2011]

Noviantro, T \& Jheng, J. C.(2010). The job satisfaction and life satisfaction relationship of Indonesian women migrant workers in Taiwan, Master's Thesis, Institute of Human Resource Mangement, NCU, Taiwan.

Rain, J. S. • Lane, I. M. \& Steiner, D. D.(1991) A current look at the job satisfaction/life satisfaction relationship: Review and future considerations, Human Relations, 44, 287 307.

Rode, J. C.(2004). Job satisfaction and life satisfaction revisited: A longitudinal test of an integrated model, Human Relations, 57, 1205 1230.

Wikipedia, http://en.wikipedia.org/wiki/igrant_ worker. [Access: 23 February, 2011]

- 논문접수일 : 2014년 03월 05일

- 심사완료일 : 1차 - 2014년 04월 08일

- 게재확정일 : 2014년 04월 09일 